\title{
Ternary Intercalation Compound of Graphite with Aluminum Fluoride and Fluorine
}

\author{
Tsuyoshi Nakajima, Masayuki Kawaguchi, and Nobuatsu Watanabe* \\ Department of Industrial Chemistry, Faculty of Engineering, Kyoto University, \\ Sakyo-ku, Kyoto 606, Japan \\ Dedicated to Prof. Dr. Drs. h. c. Oskar Glemser on the occasion of his 70th birthday
}

Z. Naturforsch. 36 b, 1419-1423 (1981); received May 7, 1981

Graphite Intercalation Compound, Graphite Fluoride

\begin{abstract}
A ternary intercalation compound of graphite with $\mathrm{AlF}_{3}$ and $\mathrm{F}_{2}, \mathrm{C}_{x} \mathrm{~F}\left(\mathrm{AlF}_{3}\right)_{y}$ was prepared under fluorine atmosphere at temperatures of $20-400{ }^{\circ} \mathrm{C}$. The typical lst stage compound has a composition of $\mathrm{C}_{6} \mathrm{~F}\left(\mathrm{AlF}_{3}\right)_{0,15}$ with a repeat distance of $940 \mathrm{pm}$. Rapid progress in the reaction led of the formation of graphite fluoride, $\left(\mathrm{C}_{2} \mathrm{~F}\right)_{n}$. ESCA spectra indicate that the chemical bond between host graphite and intercalated fluorine has nearly covalent nature similar to that for $\left(\mathrm{C}_{2} \mathrm{~F}\right)_{n}$.
\end{abstract}

A growing interest has been taken in graphite intercalation compounds of fluorides since it was found that some of them have an unique property of a high electrical conductivity. Most of them are, however, hygroscopic and unstable, which makes it difficult to apply them to a wide variety of practical fields. The intercalation of fluorides into graphite hitherto has been restricted to such fluorides as have low melting and boiling points [1]. They are gas or liquid at room temperature. In general it is necessary that an intercalant fluoride has a high vapor pressure at a relatively low temperature. For this reason it was unsuccessful to prepare graphite intercalation compounds of fluorides with high melting and boiling points or an attempt to prepare such compounds has not yet been made. In this paper we report the preparation of a graphite intercalation compound of $\mathrm{AlF}_{3}$. As mentioned above, this compound was not formed in an $\mathrm{AlF}_{3}$-graphite two components system because $\mathrm{AlF}_{3}$ has no sufficient vapor pressure even at a high temperature. The preparation was possible only under fluorine atmosphere in the range of room temperature to $400{ }^{\circ} \mathrm{C}$. With respect to the reaction temperature there is another restriction that natural graphite reacts directly with elemental fluorine at temperatures higher than $350-400{ }^{\circ} \mathrm{C}$ to give graphite fluoride $\left(\mathrm{C}_{2} \mathrm{~F}\right)_{n}$ or $(\mathrm{CF})_{n}$, which is also a kind of graphite intercalation compound having a covalent bond between carbon and fluorine [2].

* Reprint requests to Prof. Dr. N. Watanabe. 0340-5087/81/1100-1419/\$01.00/0

\section{Experimental}

Flaky natural graphite from Madagascar (grain size over $840 \mu \mathrm{m}$ or $297-840 \mu \mathrm{m}$ ) was used. The purity was $99.4 \%$ after purification with hydrogen fluoride solution. Commercial aluminium fluoride and aluminium powder were used without further purification. The reaction was carried out in a nickel reaction tube or using a thermobalance specially designed for fluorine atmosphere [3]. A trace amount of hydrogen fluoride contained in fluorine gas was removed by sodium fluoride pellets heated at $100^{\circ} \mathrm{C}$. Unreacted fluorine gas was made to react with soda lime. Graphite intercalation compounds prepared were analyzed by means of X-ray diffractometry, elemental analysis, photoelectron spectroscopy (ESCA) and differential thermal analysis (DTA). ESCA measurement was made by a Du Pont 650 B Electron Spectrometer with $\mathrm{Mg}-\mathrm{K} \boldsymbol{a}$ radiation. DTA was carried out under air, using $\alpha-\mathrm{Al}_{2} \mathrm{O}_{3}$ as a reference. Elemental analysis for $\mathrm{C}$ and $\mathrm{F}$ was performed at the Laboratory for Organic Elemental Microanalysis, Faculty of Pharmaceutical Science, Kyoto University and Al was analyzed by the atomic absorption method.

\section{Preparation of $C_{x} F\left(A l F_{3}\right)_{y}$}

A nickel vessel containing a mixture of flaky graphite (ca. $0.5 \mathrm{~g}$ ) and $\mathrm{AlF}_{3}$ (ca. $1.0 \mathrm{~g}$ ) was placed in the reaction tube and the system was evacuated by a rotary pump at $20-100^{\circ} \mathrm{C}$. Fluorine gas was then introduced into the tube to $1 \mathrm{~atm}$. After $0-1 \mathrm{~h}$, the temperature of the reaction tube was raised up to $310-400^{\circ} \mathrm{C}$ at a heating rate of $c a .4^{\circ} \mathrm{C} / \mathrm{min}$. The temperature was maintained for 24-45 h. Best results were obtained when fluorine gas was made to flow during the temperature raise. After the reaction, the reaction tube was cooled to room temperature and fluorine gas was substituted for nitrogen. The product and excess $\mathrm{AlF}_{3}$ were separated by a sieve of $297 \mu \mathrm{m}$ or a pincette. 
Preparation of $\left(\mathrm{C}_{2} F\right)_{n}$

Flaky natural graphite was put on $\mathrm{AlF}_{3}$ or $\mathrm{Al}$ powder in a reaction vessel, which was then placed in the reaction tube. After evacuation, fluorine gas was introduced into the reaction tube to $1 \mathrm{~atm}$ at room temperature. In this case reaction was facilitated with two different methods. One is that after standing for 5-6 h at room temperature, the reaction tube was heated up to $400{ }^{\circ} \mathrm{C}$ at the rate of $4.2{ }^{\circ} \mathrm{C}$ / min. Another is that after fluorine gas was introduced, the heating was carried out up to $400{ }^{\circ} \mathrm{C}$ at the rate of $30^{\circ} \mathrm{C} / \mathrm{min}$. The reaction was then continued for $5 \mathrm{~h}$ at $400^{\circ} \mathrm{C}$. The product was obtained by the same method as described previously.

Reaction of $\mathrm{AlF}_{3}$ with $\mathrm{F}_{2}$

$\mathrm{AlF}_{3}(62.9 \mathrm{mg})$ was put in the reaction vessel of a specially designed thermobalance, and the system was evacuated. Fluorine gas was then introduced into the reaction tube to $1 \mathrm{~atm}$ at room temperature. After $4 \mathrm{~h}$ the tube was heated up to 35 and $85^{\circ} \mathrm{C}$, and then fluorine pressure was reduced to $0.5 \mathrm{~atm}$ and $0.1 \mathrm{~atm}$. Through this process the weight change was monitored with an automatic transformer.

\section{Results and Discussion}

\section{$C_{x} F\left(A l F_{3}\right)_{y}$}

A reaction carried out at temperatures of 20 to $100{ }^{\circ} \mathrm{C}$ gave only a mixed stage or sometimes 2 nd stage compound. A lst stage compound was obtained when the reaction temperature was raised from $20-100{ }^{\circ} \mathrm{C}$ up to $310-400{ }^{\circ} \mathrm{C}$ after introduction of fluorine gas into the mixture of graphite and $\mathrm{AlF}_{3}$. No intercalation compound was formed when fluorine gas was introduced into the reaction system at temperatures higher than $200^{\circ} \mathrm{C}$. It was found that the introduction of fluorine gas should be made below around $100^{\circ} \mathrm{C}$ to obtain a graphite intercalation compound. On the other hand, rapid increase in the reaction rate led to the decomposition of an intercalation compound and the subsequent

Table I. Analytical data for $\mathrm{C}_{x} \mathrm{~F}\left(\mathrm{AlF}_{3}\right)_{y}$ and graphite fluoride.

\begin{tabular}{|c|c|c|c|c|c|c|c|}
\hline \multirow{2}{*}{$\begin{array}{l}\text { No. } \\
1\end{array}$} & \multirow{2}{*}{$\begin{array}{l}\text { Compound } \\
\mathrm{C}_{8} \mathrm{~F}\left(\mathrm{AlF}_{3}\right)_{0.15} \\
\text { slightly bluish black }\end{array}$} & $\begin{array}{l}\text { Elemental } \\
\text { analysis }\end{array}$ & \multicolumn{4}{|c|}{$\begin{array}{l}\text { X-ray diffraction data }(\mathrm{Cu}-\mathrm{K} \alpha) \\
\text { Int. } \quad 2 \theta\left[^{\circ}\right] \quad \mathrm{d}[\mathrm{pm}] h k l\end{array}$} & \multirow{2}{*}{$\begin{array}{l}\mathrm{I}_{\mathrm{c}}[\mathrm{pm}] \\
944^{*} \\
\pm 4\end{array}$} \\
\hline & & $\begin{array}{lr}\mathrm{C}: & 75.4 \\
\mathrm{~F}: & 21.5 \\
(\mathrm{Al}): & 3.1\end{array}$ & $\begin{array}{l}\mathrm{m} \\
\mathrm{m}, \mathrm{br} \\
\text { s } \\
\mathrm{vs} \\
\mathrm{vw}, \mathrm{br} \\
\mathrm{vw}, \mathrm{br}\end{array}$ & $\begin{array}{r}9.38 \\
16.44 \\
18.70 \\
28.44 \\
48.42 \\
58.90\end{array}$ & $\begin{array}{l}942 \\
539 \\
474 \\
314 \\
188 \\
157\end{array}$ & $\begin{array}{lll}0 & 0 & 1 \\
\text { unknown } \\
0 & 0 & 2 \\
0 & 0 & 3 \\
0 & 0 & 5 \\
0 & 0 & 6\end{array}$ & \\
\hline 2 & $\begin{array}{l}\mathrm{C}_{6} \mathrm{~F}\left(\mathrm{AlF}_{3}\right)_{0.15} \\
\text { blue-black }\end{array}$ & $\begin{array}{lr}\mathrm{C}: & 69.3 \\
\mathrm{~F}: & 26.7 \\
(\mathrm{Al}): & 4.0\end{array}$ & $\begin{array}{l}\mathrm{w}, \mathrm{br} \\
\mathrm{m} \\
\mathrm{vs} \\
\mathrm{vw}, \mathrm{br} \\
\mathrm{vw}\end{array}$ & $\begin{array}{r}9.72 \\
18.98 \\
28.32 \\
48.7 \\
59.26\end{array}$ & $\begin{array}{l}909 \\
467 \\
315 \\
187 \\
156\end{array}$ & $\begin{array}{lll}0 & 0 & 1 \\
0 & 0 & 2 \\
0 & 0 & 3 \\
0 & 0 & 5 \\
0 & 0 & 6\end{array}$ & $\begin{array}{l}940^{*} \\
\pm 6\end{array}$ \\
\hline 3 & $\begin{array}{l}\mathrm{C}_{17} \mathrm{~F}\left(\mathrm{AlF}_{3}\right)_{0.45} \\
\text { black, slightly exfoliated }\end{array}$ & $\begin{array}{lr}\mathrm{C}: & 78.4 \\
\mathrm{~F}: & 16.9 \\
\text { (Al): } & 4.7\end{array}$ & $\begin{array}{l}\mathrm{w}, \mathrm{br} \\
\mathrm{m} \\
\mathrm{s} \\
\mathrm{vw}, \mathrm{br} \\
\mathrm{vw}, \mathrm{br}\end{array}$ & $\begin{array}{r}9.60 \\
18.94 \\
27.80 \\
47.4 \\
58.0\end{array}$ & $\begin{array}{l}920 \\
468 \\
321 \\
192 \\
159\end{array}$ & $\begin{array}{lll}0 & 0 & 1 \\
0 & 0 & 2 \\
0 & 0 & 3 \\
0 & 0 & 5 \\
0 & 0 & 6\end{array}$ & $\begin{array}{l}950^{*} \\
\pm 14\end{array}$ \\
\hline 4 & $\begin{array}{l}\text { intermediate product } \\
\text { black, exfoliated }\end{array}$ & $\begin{array}{ll}\text { C: } & 73.4 \\
\text { F } & 26.8\end{array}$ & $\begin{array}{l}\text { vw, br } \\
\text { vs } \\
\text { vw, br }\end{array}$ & $\begin{array}{l}11.16 \\
27.40 \\
56.10\end{array}$ & $\begin{array}{l}792 \\
\\
325 \\
164\end{array}$ & $\begin{array}{lll}0 & 0 & 1\end{array}$ & $\begin{array}{l}\text { for graphite } \\
\text { fluoride }\end{array}$ \\
\hline 5 & $\begin{array}{l}\text { graphite fluoride } \\
\text { gray, exfoliated }\end{array}$ & $\begin{array}{l}\mathrm{C}: \quad 47.4 \\
\mathrm{~F}: \quad 50.7 \\
\left(\mathrm{C}_{2} \mathrm{~F}\right)_{n}: 65 \% * *\end{array}$ & $\begin{array}{l}\mathrm{s}, \mathrm{br} \\
\mathrm{w}, \mathrm{br}\end{array}$ & $\begin{array}{l}11.42 \\
41.52\end{array}$ & $\begin{array}{l}774 \\
217\end{array}$ & $\begin{array}{lll}0 & 0 & 1 \\
1 & 0 & 0\end{array}$ & \\
\hline 6 & $\begin{array}{l}\text { graphite fluoride } \\
\text { gray, exfoliated }\end{array}$ & $\begin{array}{l}\mathrm{C}: \quad 49.5 \\
\mathrm{~F}: \quad 50.7 \\
\left(\mathrm{C}_{2} \mathrm{~F}\right)_{n}: 71 \% * *\end{array}$ & $\begin{array}{l}\mathrm{s}, \mathrm{br} \\
\mathrm{w}, \mathrm{br}\end{array}$ & $\begin{array}{l}11.10 \\
42.12\end{array}$ & $\begin{array}{l}789 \\
214\end{array}$ & $\begin{array}{lll}0 & 0 & 1 \\
1 & 0 & 0\end{array}$ & \\
\hline
\end{tabular}

* Repeat distance for $\mathrm{C}_{x} \mathrm{~F}\left(\mathrm{AlF}_{3}\right)_{y}$ was calculated from $(00 l)$ diffraction lines except broad (00 l) lines.

** The content of $\left(\mathrm{C}_{2} \mathrm{~F}\right)_{n}$ was calculated on the assumption that the product contains only $(\mathrm{CF})_{n}$ as an impurity. By representing the amounts of $\left(\mathrm{C}_{2} \mathrm{~F}\right)_{n}$ and $(\mathrm{CF})_{n}$ as $x$ and $1-x$ respectively, $\mathrm{F} / \mathrm{C}$ ratio is related with $x$ by the following equation: $\mathrm{F} / \mathrm{C}=1-(1 / 2) \cdot x$. 


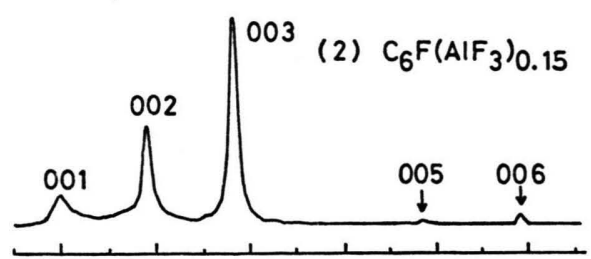

(4) intermediate
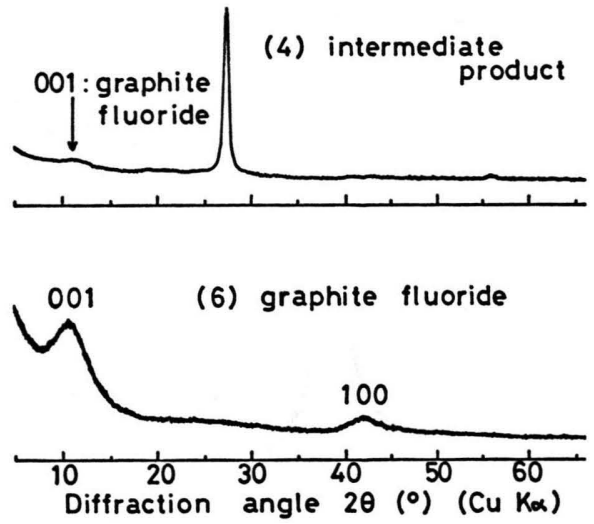

Fig. 1. Change in X-ray diffraction patterns of the products.

formation of graphite fluoride with a covalent bond between carbon and fluorine.

Table I shows the results of elemental and X-ray analyses of the intercalation compound and graphite fluoride. Typical X-ray diffraction patterns of these compounds are given in Fig. 1. Intercalation compound 2 was blue-black in color, whereas compound 1 into which the intercalant was not fully inserted was slightly bluish black. Compound 3 is one which was already slightly decomposed by loss of some fluorine molecules. These compounds were so stable that their exposure to air for 1 day or immersion in water overnight could affect no change in their $\mathrm{X}$-ray diffraction patterns. However, they released a trace amount of fluorine during their storage in a glass ampul for more than 2 weeks. As a result the glass ampul was slightly corroded. The peak position of the $(00 l)$ diffraction line was shifted to lower angle by $c a .30 \mathrm{pm}$ and the half width was also broadened. Fig. 2 is the DTA curve for compound $\mathbf{1}$, which began to decompose at $52{ }^{\circ} \mathrm{C}$, giving an exfoliated residue through two exothermic peaks.

For a typical intercalation compound 2 a composition of $\mathrm{C}_{6} \mathrm{~F}\left(\mathrm{AlF}_{3}\right)_{0.15}$, was determined from a sample kept in a glass ampul for more than 3 months. Atomic absorption spectra for $\mathrm{Al}$ gave smaller scattered values than expected, probably because

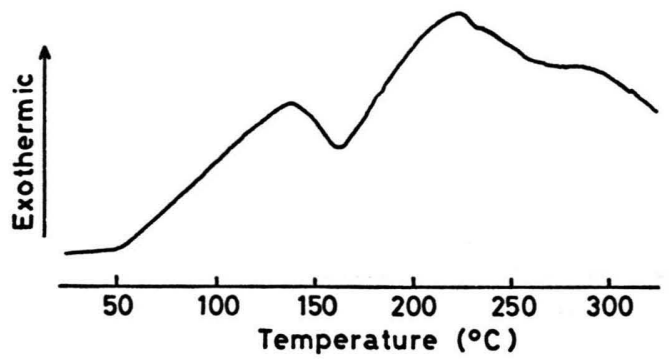

Fig. 2. DTA curve for $\mathrm{C}_{8} \mathrm{~F}\left(\mathrm{AlF}_{3}\right)_{0.15}$ in air. Heating rate: $20^{\circ} \mathrm{C} / \mathrm{min}$.

$\mathrm{AlF}_{3}$ was not completely dissolved into aqueous solution, remaining between graphite layers. The analytical value for $\mathrm{Al}$ was therefore determined by subtracting those for $\mathrm{C}$ and $\mathrm{F}$ from $100 \%$. The intercalant has more than 3 fluorine molecules to one $\mathrm{AlF}_{3}$, which suggested us to use this intercalated fluorine as an oxidizing agent. When compound 1 was immersed in KI solution for several days, the color of the solution changed to yellow.

In an X-ray diffraction study of these intercalation compounds, broad diffraction lines were often observed. The intercalant might take slightly disordered orientation because of the low vapor pressure and mobility of the $\left(\mathrm{AlF}_{3}\right)_{m} \cdot\left(\mathrm{F}_{2}\right)_{n}$ complex. The repeat distance, $I_{c}$, was calculated from $(00 l)$ diffraction lines to be $940-950 \mathrm{pm}$, which is by $c a .100 \mathrm{pm}$ larger than in other lst stage compounds of fluorides [1]. As shown in ESCA spectra, the chemical bond between intercalated fluorine and carbon of the graphite layer is similar to that in graphite fluoride $\left(\mathrm{C}_{2} \mathrm{~F}\right)_{n}$. This means that intercalated fluorine is situated in contact with carbon of graphite. Provided that intercalated $\mathrm{AlF}_{3}$ is sandwiched between two sheets composed of fluorine atoms, the dimension of the intercalant becomes $c a .600 \mathrm{pm}$, which is well consistent with the observed value of $605 \mathrm{pm}$ $(=940-335 \mathrm{pm})$. If the intercalation compound prepared would be a second stage one, only a narrow interlayer gap of $270 \mathrm{pm}$ would remain to accomodate the aluminum fluoride. It is therefore reasonable that $\mathrm{C}_{x} \mathrm{~F}\left(\mathrm{AlF}_{3}\right)_{y}$ in Table $\mathrm{I}$ is regarded as a first stage compound.

\section{Graphite fluoride $\left(\mathrm{C}_{2} \mathrm{~F}\right)_{n}$}

Graphite fluoride, $\left(\mathrm{C}_{2} \mathrm{~F}\right)_{n}$ prepared in this study has the same appearance in shape as exfoliated graphite (see Fig. 3). Exfoliation of graphite is caused by release of intercalant with increase in 


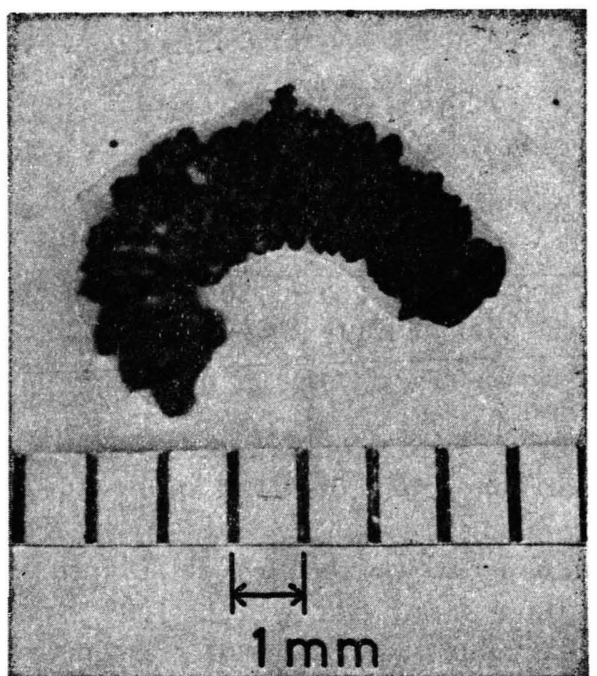

Fig. 3. Photomicrograph of exfoliated $\left(\mathrm{C}_{2} \mathrm{~F}\right)_{n}$.

temperature. It is considered that graphite fluoride is formed through the decomposition of the intercalation compound and subsequent fluorination of exfoliated residue.

Graphite $+\mathrm{AlF}_{3}+\mathrm{F}_{2} \rightarrow \mathrm{C}_{x} \mathrm{~F}\left(\mathrm{AlF}_{3}\right)_{y} \frac{\mathrm{F}_{2}}{300-400^{\circ} \mathrm{C}} \longrightarrow$ $\left(\mathrm{C}_{2} \mathrm{~F}\right)_{n}+\mathrm{AlF}_{3}$.

This reaction process is also understandable from Fig. 1 and Table $\mathrm{I} . \mathrm{C}_{17} \mathrm{~F}\left(\mathrm{AlF}_{3}\right)_{0.45}$ is a slightly decomposed intercalation compound losing ca. 2 fluorine molecules. The intermediate product 4 shows two kinds of diffraction lines attributed to graphite fluoride and an intercalation compound with a rather wide repeat distance.

In order to prepare $\left(\mathrm{C}_{2} \mathrm{~F}\right)_{n}$ by this process, rapid progress in the reaction is necessary. It was accomplished either by insertion of many intercalants into graphite at room temperature or by rapid increase in temperature. Even under mild conditions for the intercalation reaction, prolongation of reaction time i.e. a reaction over several days leads to the formation of graphite fluoride. Recently we investigated the fluorination of exfoliated graphite with elemental fluorine and obtained as a result that graphite fluoride, $\left(\mathrm{C}_{2} \mathrm{~F}\right)_{n}$ was prepared with high reaction rate as compared to the reaction rate of natural graphite [4]. According to the above method, $\left(\mathrm{C}_{2} \mathrm{~F}\right)_{n}$ is prepared by a more simple process and higher reaction rate.

\section{ESCA spectra}

ESCA is one of the most useful means to give us valuable information concerning a chemical bond between host graphite and intercalant. Graphite fluoride, $\left(\mathrm{C}_{2} \mathrm{~F}\right)_{n}$ has two carbon ls peaks at $289.0 \mathrm{eV}$ and $287.0 \mathrm{eV}$ relative to contamination carbon ls peak located at $284.0 \mathrm{eV}$. The $\mathrm{C}_{1 \mathrm{~s}}$ peak at $289.0 \mathrm{eV}$ is derived from $\mathrm{C}-\mathrm{F}$ bonds and that appearing at $287.0 \mathrm{eV}$ corresponds to $\mathrm{C}-\mathrm{C}$ bonds adjacent to $\mathrm{C}-\mathrm{F}$ bonds [2]. Since (CF) ${ }_{n}$ type graphite fluoride has only C-F covalent bonds, the ESCA spectrum has also only one $\mathrm{C}_{1 \mathrm{~s}}$ peak at $289.0 \mathrm{eV}$.
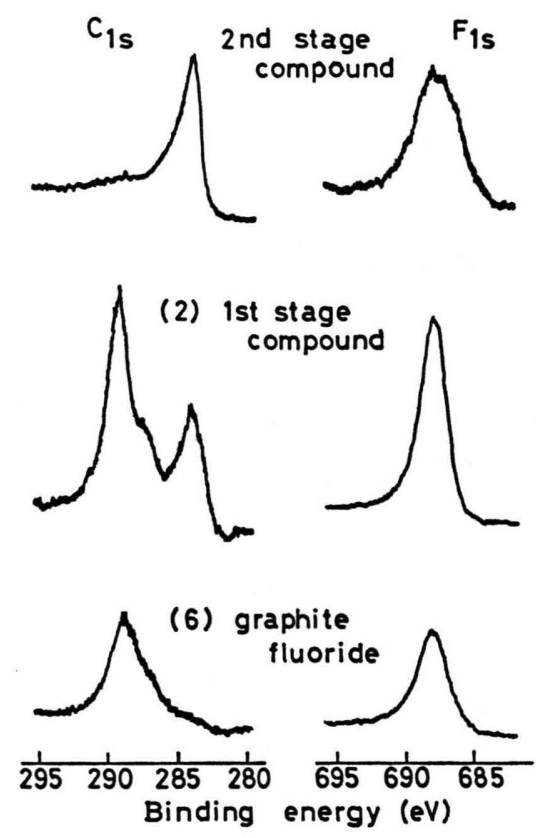

Fig. 4. ESCA spectra for $\mathrm{C}_{x} \mathrm{~F}\left(\mathrm{AlF}_{3}\right)_{y}$ and graphite fluoride.

The 2nd stage compound $\left(I_{c}=1270 \mathrm{pm}\right)$ prepared at room temperature showed a strong peak at $284.0 \mathrm{eV}$ and a broad shoulder in the range of $286 \mathrm{eV}$ to $291 \mathrm{eV}$. The latter suggests the presence of fluorine atoms chemically adsorbed and covalently bonded to carbon atoms of host graphite. The $\mathrm{F}_{1 \mathrm{~s}}$ spectrum also gave a rather broad peak at $687.6 \mathrm{eV} . \mathrm{C}_{1 \mathrm{~s}}$ peaks for $\mathrm{C}_{6} \mathrm{~F}\left(\mathrm{AlF}_{3}\right)_{0.15}$ were situated at the same positions as those for graphite fluoride mainly composed of $\left(\mathrm{C}_{2} \mathrm{~F}\right)_{n}$, which indicates that the chemical bond between host graphite and intercalated fluorine has nearly covalent nature similar to that for $\left(\mathrm{C}_{2} \mathrm{~F}\right)_{n}$. Higher mixed stage compounds 
were very often formed in reactions made below $100{ }^{\circ} \mathrm{C}$. It was necessary to raise the reaction temperatures up to $310-400^{\circ} \mathrm{C}$ in order to prepare a lower stage compound even if it was a mixed stage one. From the results of ESCA measurements, it is supposed that the intercalant molecules inserted into graphite under fluorine atmosphere are partly released when atmospheric fluorine gas is removed from the reaction system. Accordingly the increase in reaction temperature would be required to bring the intercalants in an ordered structure and to strengthen the chemical interaction of intercalated fluorine with the host graphite.

\section{Intercalation mechanism of $A l F_{3}$ and $F_{2}$}

The intercalation compound $\mathrm{C}_{x} \mathrm{~F}\left(\mathrm{AlF}_{3}\right)_{y}$ was prepared in the range of room temperature to $400^{\circ} \mathrm{C}$ where $\mathrm{AlF}_{3}$ itself has no considerable vapor pressure. In fact no intercalation compound was formed in the $\mathrm{AlF}_{3}$-graphite system. The reaction of $\mathrm{AlF}_{3}$ with $\mathrm{F}_{2}$ was performed on a thermobalance and the weight change was monitored. As soon as fluorine gas was introduced into the reaction tube at room temperature, the weight began to decrease, being lighter by $2.8 \mathrm{mg}$ than the original weight in $10 \mathrm{~min}$ after the introduction of fluorine gas to $1 \mathrm{~atm}$ had finished. The weight decreased still continuously and reached a constant value, when the decrease in weight was $4.4 \mathrm{mg}$.

The increase in temperature up to $85^{\circ} \mathrm{C}$ resulted in no change in weight of $\mathrm{AlF}_{3}$. However, the weight was recovered again when the fluorine pressure was reduced to $0.1-0 \mathrm{~atm}$. From this result, it was considered that the gaseous species of $\left(\mathrm{AlF}_{3}\right)_{m} \cdot\left(\mathrm{F}_{2}\right)_{n}$ was formed by the reaction of $\mathrm{Alf}_{3}$ with fluorine gas. $m \mathrm{AlF}_{3}(\mathrm{~s})+n \mathrm{~F}_{2}(\mathrm{~g}) \rightleftharpoons\left(\mathrm{AlF}_{3}\right)_{m} \cdot\left(\mathrm{F}_{2}\right)_{n}(\mathrm{~g})$.

Gaseous species $\left(\mathrm{AlF}_{3}\right)_{m} \cdot\left(\mathrm{F}_{2}\right)_{n}$ would be intercalated into graphite.
[1] H. Selig and L. B. Ebert, Adv. Inorg. Chem. Radiochem. 23, 281 (1980).

[2] Y. Kita, N. Watanabe, and Y. Fujii, J. Am. Chem. Soc. 101, 3832 (1979).
[3] N. Watanabe, Solid State Ionics 1, 87 (1980).

[4] N. Watanabe, A. Izumi, and T. Nakajima, J. Fluorine Chem., in press. 